\title{
Children Abuse: The Credibility of the Victim's Testimony in the Brazilian Justice
}

\author{
Diego Alex de Matos Martins \\ Universidade Federal do Pará \\ Programa de Pós-graduação em Segurança Pública \\ Brasil \\ Jaime Luiz Cunha de Souza \\ Universidade Federal do Pará \\ Programa de Pós-graduação em Segurança Pública \\ Brasil
}

\begin{abstract}
This text discusses the care of children and adolescents victims of sexual abuse and the credibility of its narrative in justice institutions. Documentary analysis was carried out in seventy-nine cases sentenced in the Special Court for Children and Adolescents of the city of Belem in the year of 2017. The main findings of the survey indicate the existence of a controversy in relation to the credibility of the testimony of children victims of abuse, the positive and negative aspects of the practice of professionals responsible for mediating the collection of such statements and the precariousness of technical instruments and the human material placed at the disposal of justice, whose shortage directly impacts on the final result of the judgments, generating impunity and new victimization of children.
\end{abstract}

Keywords: Sexual abuse; Customer Service; Credibility; Testimony; Justice

\section{Introduction}

This work has as objective to discuss the inconveniences and inadequacies in the way the Brazilian justice deals with the testimony of children who have been victims of sexual abuse - sexual abuse and rape herein are regarded as similar conditions. 79 processes that were in progress in the Special Court for Children and Adolescents were analyzed in the judicial district of Belém, selected due to being considered cases of abuse and/or rape sentenced in the year 2017.

In the last fifteen years, countless studies have been published about abuse suffered by children, among which Alexandre Nadanovsky, Moraes, and Reichenheim (2010), Alexandre et al are highlighted. (2011), Da Silva Franzin et al. (2014) about the socio-demographic variables and the seriousness of the abuses, Bidarra, Lessard, and Dumont (2016) about the family structure where the abuse occurs, Viola et al. (2016) on the geographic and economic factors involved in this issue and also William, Duarte, Farias, and Steidel, (2016) on the effects of post-traumatic abuse suffered by the children.

Although there is a significant amount of publications about the conditions in which the abused child is inserted as the deponent in judicial processes, we can highlight the important developments that are in the studies ofHabigzang et al. (2008), Habigzang, Ramos, and Koller $(2005,2011)$.On the victims' profile, their families and their aggressors carried out from judicial proceedings, Granjeiro and Costa (2008) about the factors that subsidize the judicial process and Da Costa and Da Silva (2016) on the conviction of the judge and the typification of the evidence in the Brazilian Penal Code.

Works that deal specifically with the testimony of the abused child are less frequent, among which deserve to be highlighted Froner and Ramires (2008) and Ribeiro (2009) that discuss the methodologies of listening to this type of victim in the judiciary scope, Dobke (2001) and Dobke, Dos Santos , and Dell'aglio (2010) about testimonials of adolescents in criminal proceedings and Schaefer, Rossetto, and Kristensen (2012) on the role of the Legal expertise and the participation of the legal expert in the case of abuse and the legislation support for the legal report. However, we believe that it is possible to go further in this discussion addressing the question of the credibility of the testimony of a child victim of abuse in their testimonies in the Judiciary. 
The discussion we propose is organized into three topics: at first, we present arguments harvested in the international debate about the credibility of the children's testimony; in the second, we show the main differences between the strategy adopted in Brazil for the collection of this kind of testimony and the form as it occurs in other countries; third, we present a panorama of the testimonies of children in the Special Court for Children and Adolescents in the judicial district of Belém city.

\section{The question of credibility in the experience of other countries}

The concerns with testimonials from children are already well developed in several countries, especially those where the laws of childhood protection have a more consolidated history. However, even in these countries, such statements have been the object of many controversies regarding the abused children's capacity on saving and verbalizing reliable information about the abuse suffered.

Discussions on the child's memory are often used to put in doubt the credibility of its reports and hinder the abuser's punishment. Studies conducted in Europe, in the United States (USA), in Australia and in Latin America have shown that the mistrust of the courts in relation to the veracity of statements, in addition to the fact that the majority of abusers is known to the victim, almost always family members or people who with her live with a certain intimacy, a situation that gives rise to all kinds of pressures and constraints so that the victim does not denounce or change her report in the judicial process (Dobke, 2001; Feltis, Powell, Snow, \& Hughes-Scholes, 2010).

The mistrust environment greatly impacts the judges and lay people on the occasion of the trials of those accused of abuse. It is noteworthy that, in the USA, for example, the judgment of these cases is carried out by a jury, unlike Brazil, where both the trial and the conviction are performed by the judge. Buck, London, and Wright (2010) found that the jurors usually have an ambiguous position in relation to the credibility of the testimony given by the children; the authors explain that, if, on the one hand, the jurors tend to believe that children can be important witnesses, on the other hand, they tend to admit that they are suggestible and that their reports can be manipulated. This ambiguity in relation to the report credibility is particularly relevant in cases in which there are no material traces or eyewitnesses. With the credibility of the report seriously questioned, its potential is radically reduced to determine the outcome of the defendant's trial (Johnson \& Shelley, 2014). The victim obliged to testify in these conditions, as a rule, will suffer new victimization. Goodman-Delahunty, Cossins, and O'Brien (2010), based on research carried out in Australia, found that children who are victims of sexual abuse have been forced to make vaginal and anal examinations, which certainly adds suffering and constraints which are additional to those already incurred during the abuse. Despite the distrust in relation to the children's testimony, there studies, such as Cooper, Quas, and Cleveland (2014), Golding, Lynch, Wasarhaley, and Keller (2015) and Golding, Wasarhaley, Lynch, Lippert, and Magyarics (2015) that prove that small children's testimonies are more reliable than that of adolescents.

These authors explain that the presence of an external expert, usually a psychologist or medical expert, aims to determine the conditions in which the abuse occurred and assess the child's ability to separate the realityfrom fantasy. These authors found that the importance given to the presence of a specialist is the belief that his or her report, essentially technical, can translate to the level of understanding of other interested parties regarding what the expert reports presented under a complex language. Ultimately, the victim's credibility depends fundamentally on the report which the specialist will provide, which can confirm his or her report or discredit it completely.

Golding et al. (2015) and Golding et al. (2015) showed that there was a greater number of convictions when in the process there were testimonies of additional witnesses, technicians or specialists, and that the jurors were ten times more likely to issue condemnatory decisions when the process was the testimony of a specialist trained to provide clarifications in judgment. Goodman-Delahunty et al. (2010)draw attention to a detail: the testimony of experts only confers credibility to the testimony of victims when it is done in judgment before the testimony of the victim and, in advance, confirms what the child will later report. This particular situation denotes one of the significant differences in relation to the dynamics of the Brazilian criminal procedure, because, in Brazil, this procedure is only possible when the defense of the defendant agrees with the inversion of the legal order of the hearing ofthe enrolled persons, agreement that will only occur if the lawyer realizes that such action is beneficial to his or her client.Besides the testimony of an expert, there are other factors that can alter the level of the victim's credibility. The fact that someone in the family sits next, in a position in which it is possible an exchange of glances, might, according to McAuliff, Lain and Michel (2015), lead to the questioning of the credibility of evidence under the allegation that this presence could induce the child's testimony, thus making it less reliable. 
Cooper et al. (2014) observed that emotional manifestations of the victim may have ambiguous effects on the jurors, depending on the sex of the child: emotional manifestations can be seen as a sign of the credibility of the report, especially in female child. The authors also observed that the same demonstrations of emotion when in male children, mainly over six years, tend to lose credibility before the jurors due to societal expectations in relation to how boys and girls express their feelings. They concluded that the jurors of the female sex that witnessed strongly emotional statements on the part of the victim, especially of children with little age, tended more to assume condemnatory postures.

Golding et al. (2015) and Golding et al. (2015) found results that confirm the influence of gender condition of the jurors in the outcome of the trial and consequently on the victim's credibility They present data that indicate that female jurors are more prone to believe in speaking of the victims than the male sex jurors. They suggest that such empathy with the victims is due to the fact that women are more often the target of sexual abuse than men; as for the male jurors, according to the authors, tend to appreciate the presence of the additional witness, mainly of the expert or specialist.

Buck et al. (2010) draw attention to the fact that this kind of overrating the testimony of an expert tends to reduce the credibility of the victim's testimony. In addition, the credibility of the narrative may also be influenced by the guidelines that the child receives before starting the testimony and the way in which the questions are formulated (Ahern, Stolzemberg, \& Lyons, 2015).These authors recommend that children are oriented to say "I do not know" when they really do not know the answer to a question or to ask to repeat when they do not understand what was asked, because this action tends to make them more comfortable to report the abuse that they were victim. Upon commenting on the procedures for examination in the courts, north americans describe that, prior to the start of the testimony, the child is asked about their understanding of the meaning of concepts such as "true" or "false".

Evans, Stolzenberg, Lee, and Lyon (2014) )andFeltis, Powell, Snow, and Hughes-Scholes (2010) emphasize that the type of question asked the child can have a decisive role in respect to the richness and the detailing of her report. They explain that "closed questions", i.e., those to whom the child would answer affirmatively or negatively are less efficient for the verification of the facts rather than the "open questions", which allow the child to particularize better the abuses they have suffered. Similar conclusions are present in the work of Buck et al. (2010), in their analysis of the reliability of the reports produced with the use of "open questions". However, these authors did not rule out the possibility that the child's memory about certain facts can be manipulated and that she manifests a report which does not correspond to reality.

One of the difficulties encountered in dealing with issues relating to the children's abuse is determined by the moral and legal requirement to give an adequate response to the seriousness of the crime committed with the aim to eradicate this type of criminal behavior in society and at the same time not to violate the legal guarantees due to the accused person, such as the presumption of innocence and the right to a wide defense. The solution to this dilemma has no simple or easy answers because the judgments of credibility of the victim or the guilt of the accused person have no basis in the various narratives that make up the process, but in a mixture sometimes little consistent of forensic evidences and emotional narratives, of greater or lesser empathy for the victim, therefore with an extremely heavy load of subjectivity on the part of the people in charge of judging.

\section{Network of care and credibility of the testimony}

In Brazil, the processes that involve abuse of children do not go to jury trial, unless the abuse results in murder. Thus, if the rape is followed by death (Article 213, paragraph 2 of the Criminal Code), the competence is of the Single Trial, that is, the process will not go the jury trial. However, if the police investigations show that the accuser's intention from very beginning was to kill the child, the process will go the jury. The cases of abuse without this outcome are judged by the judge in charge of the process, who participates in the hearing of the testimonies and the questioning of the victim, witnesses and the defendant. In order to preserve the victim of a second victimization, it was adopted in Brazil the already existing practice in other countries to create differentiated conditions for hearing the child's testimony through the procedure conventionally called "special testimony".

In this type of testimony, the victim makes his or her narrative directly to a psychologist or social worker in place specially prepared to receive it, located in the building of the Court of Justice, without the presence of parents or guardians. 
However, as this type of installation does not exist in most of the courts, the most common is that the victim provides clarification directly to the judge in the presence of his or legal guardian. One of the drawbacks of this type of statement carried out in an environment without the characteristics that would be destined to the special testimony is that, during the victim's questioning and as the questions are formulated, it is established a veiled communication by means of an exchange of glances between the victim and his or legal guardian, which gives the impression to those who attend to be experiencing an authorization request for a response. According to McAuliff et al. (2015), this type of behavior indicates that the child does not feel comfortable in that environment, but, in the eyes of others present, can give impression of there being there an interference of the adult in the content of the response, which somehow ends up producing mistrust in relation to what is said by the child.

It still persists in Brazil a series of obstacles that put in doubt the quality of thetestimony during the operationalization of special testimony. The drawbacks range from thenon-universalization of the deployment of special rooms until the inadequacy or lack of specialized training of the people in charge for harvesting this type of testimony. The most damaging consequences of this unpreparedness appear mainly in the courts that failed to set up such differentiated rooms and the hearing of the abused child in the traditional manner. Dobke (2001) clarifies that few practitioners have adequate training to understand the dynamics of child abuse; such incompetence is inevitably reflected in difficulty questioning properly and efficiently the child. This fact directly influences in the exploitation of the victim's report, to the extent that the spontaneity and the accuracy of the answers depend on how questions are formulated, and the relationship of trust established with the child, a bond whose construction requires time and a lot of experience of the person responsible to act as a facilitator of the talks of the victim.

Although the scope of justice is essentially the habitat of the law operators, many of them resist qualifying for acting in the collection of testimony from children, under the allegation that such preparation requires time and money. In addition, the social expectation in relation to these professionals must be firm and impartial, turning this "dive' into a different area of his or her academic background, in which the sensitivity reveals itself as the fundamental characteristic, a displacement of his or comfort zone is not always considered attractive. It should be noted that these statements were collected in informal dialogs maintained by researchers with prosecutors and defenders that act on the Criminal Court for Children and Adolescents and express their personal perceptions regarding this issue.

Although it is believed that that some professional categories receive since the beginning of their formation a technical knowledge more suited to deal with abused children, especially in the area of health, social assistance and psychology, there is no consensus regarding the outcome of the interventions carried out by these professionals about the credibility of the child's testimony. To the extent that the psychological report is overvalued, there is a possibility that the weight of the victim's testimony tends to decrease, and it is not clear whether this is the best strategy to make justice (Ahern et al., 2015; Buck, London, \& Wright, 2010; Dobke, 2001; Granjeiro\& Costa, 2008; Habigzang et al., 2008; Schaffer, Rosetto, \& Kristensen, 2012).

There are also dormant questions regarding the duty of professional secrecy, which would be violated before the actuation of a specialized professional. Such objection remains present, even knowing that the criminal evidence obtained with the aid of these professionals has improved in quality and became more reliable, the child's testimony (Evans, Stolzenberg, Lee, \& Lyon, 2014; Golding, Lynch, Wasarhaley, \& Keller, 2015; Golding, Wasarhaley, Lynch, Lippert, \&Magyarics, 2015).Considering the point of view of the Defendant and his or her defense, the insertion of a specialized professional as the determinant of the process could signify allegation of injury to the right of defense, to the extent that the accused person could not confront the victim and his or her report at the time that it is uttered, whose right is provided in Article 217 of the Code of Criminal Procedure.

The Brazilian Penal Code does not foresee the need for special procedure for taking testimony of victims of sexual crimes, nor determines any action concerning the construction of special spaces where such procedure is done with the greatest care to save the victim from suffering. The experiences that resulted in the installation of rooms with this purpose began with measures implemented in state courts, such as, for example, the pilot project implemented in 2003 in the 2nd Juvenile Court of Childhood and Youth of the Central Trial of the Judicial District of Porto Alegre, on account of the need to improve the quality of the evidence of sexual crimes offenses. 
According to Allan (2007), in the traditional testimony, without the use of technical ability and without the necessary care with the child protection, there are great chances of occurring a new violence against the victim, the so-called "secondary victimization". According to this author, this risk decreases when it is adopted the socalled "special testimony".

Since the decade of 80 of the 20th century and especially with the enactment of the Federal Constitution in 1988 and the Statute of the Child and Adolescent in 1990,there has been sparse discussions about the child's testimony, the ways to collect it and its credibility, but it was mainly from the years 2000 that the discussion has gained a little more consistency because it was found that these factors influenced directly on how the judges evaluated the credibility of the victim's report and how they delivered the sentences (Allan, 2007; Dobke, 2001). Since the beginning of the year 2000, Dobke (2001) warned: the interlocutor needs to position himself or herself properly before the child, give her permission to reveal the secret, to encourage the "complaints" given by her, understand the child's language, and finally, create an empathy that allows to ask questions and obtain answers without causing secondary damages to the victim. Another important providence assimilated from the experience of other countries was the adoption of care as to how the child is interviewed, resulting from the awareness of the negative impact that the neglect of this type of action could have on the quality of her testimony, mainly in what concerns the relationship of trust that needs to be established with the victim. This need had already been discussed at the workof Buck et al. (2010).

Despite the strength of the Regional Councils of Psychology and Social Service, there has been a considerable increase in the number of courts that they have installed consisting of a special testimony. According to Dobke (2001), regarding the initial controversial issues, the experience was assessed as successful and gradually replicated in several other cities of the country, to the extent to signify the enactment of Law no. 13.431, dated from April 4th of 2017, which establishes the system of guarantee of the child's and adolescents' rights victims or witnesses of violence.

Law no. 13.431 introduced important elements of experience already consolidated in other countries. For example, the implementation model for differentiated spaces to collect the child's testimony hassimilarities with the model adopted in the courts of the United States, as pointed out by Golding et al.(2015). Other aspects that took part in the planning of special rooms were described in the work of Ahern, Stolzenberg and Lyon (2015), especially regarding the expert valuation and the psychological evaluation of cases in which there are no trace materials or eye-witnesses to prove the existence and the author of the crime.

Another factor which gave emphasis on the quality of the child's testimony was a certain understanding of the extent and severity of the problem, because the demand for action took such a proportion that it was impossible to ignore the negative social impact produced by sexual violence against children. Data from the Brazilian Public Security Yearbook published in 2018 show that in the year 2016 49,497 cases of rape were registered in Brazil ,ch corresponds to a rate of 24 rapes per 100,000 inhabitants.

If we compare the difficulties of installation of special testimonies rooms in Brazil with the way this issue is dealt with in the United States, for example, we will see a huge lag, because in that country there are more than 800 specialized locations for children's reception. One of the main concerns is to reduce the number of interviews to which children are subjected on account of the criminal proceedings, to alleviate the trauma and the second victimization, as a result of what a prolonged exposure could cause (Bidrose\& Goodman, 2011; Buck et al., 2010; Hobbs \& Goodman, 2014).

In Brazil, the child victim is removed from the courtroom and forwarded to another ready to collect her testimony. According to Dobke (2001), this special room is connected by cameras and microphones with the courtroom, and the whole dialog is seen and heard in real time by everybody who is there. The person who conducts the interview is a Psychologist or a Social Worker, and all parties (prosecutor, judge and the defendant's lawyer) may ask questions to the child through an electronic point directly connected to the person responsible for performing the interview, which will introduce the issue in dialog with the child. In this aspect, there is a significant difference between the special rooms installed in Brazil and those that exist in the United States: while in Brazil the special rooms are located in buildings where Court of Justice operates and are linked to the branches specialized in trials of this type of crime, in the USA these spaces are not in the building of the courts, they form a network coordinated by the National Children's Alliance (NCA), an association that works in the fifty U.S. states and adds approximately 850 Children's Advocacy Center (CAC), with a multidisciplinary composition aimed at medical, psychological, legal support and other services provided to a child victim of abuse.

112 
In Brazil, the accused person does not go to the Jury Trial, being judged by a judge. The judge decides on the guilt and applies the penalty it deems appropriate, in accordance with his or her assessment of the quality of the evidences and the limits established by law. In the United States, this type of crime is forwarded to the Jury Trial, and the juror decides on the guilt or innocence of the defendant, and the judge will only quantify the sentence. The care to children in places where special testimonials is carried out occurs as pre-procedure, i.e., as a preparatory measure to the process, whose purpose is to reduce the number of testimonials that the victims eventually would have to make in judgment. In Brazil, the child's testimony is done as a measurement procedure; thus, a possibly unsafe or faltering behavior during the collection of her testimonial goes to the process directly at the expense of evidence required, without taking into consideration the inconvenience and the imprecision technique of testimony taken under this circumstance, which reveals much more about the child's discomfort $d$ than the untruth of her report.

\section{Characteristics of the assisted of victim of abuse in Belém}

In 2016, according to the Atlas of Violence the edition of 2018, only in the state of Pará, 3002 occurrences of rape were recorded, which amounts to an average of 36 occurrences for each 100 thousand inhabitants. In 2017, according to data extracted from the Libra system, used by the Court of Justice of the state of Pará in the management of procedural information, Criminal Court for Children and Adolescents ofBelém received 567 new cases, 193 of which were related to the crime of rape of vulnerable victims. By the end of that year, only 79 cases were sentenced to a volume that included the processes that were in progress and the new ones who arrived in 2017.

The infrastructure that the Civil Police offers in Belém to deal with the crime of child abuse is different from that which is provided by the Judiciary. In the Civil Police, there is only a specialized police station for the crime of sexual abuse and rape of vulnerable victims, which caters to almost all of the metropolitan region of Belém - a world population of approximately 2.5 million inhabitants (IBGE, 2010). This police station, even specialized, does not have a room prepared or equipped to make the collection of the testimony of a child victim of abuse.

As part of the assistance network in the context of the Civil Police, there are also the actions of the program of the government of the state of Pará called Propaz Integrado. This program is intended for the treatment of a victim of abuse, but also assists children and adolescents involved in other crimes. Among the measures that are part of Propaz routine, the main ones are geared to the sending for forensic examination, for the psychological care and support for the police authority responsible for investigating the case; however, this initial assistance does not exempt the victim from repeating his or her report several times and appear in court to repeat it moments later. Although each municipality in the metropolitan region of Belém has a probate court to deal with abuse of vulnerable victims of all age groups, the only specialized in crimes against children is the Criminal Court for Children and Adolescents of Belém, which receives the processes of seven municipalities which, together, gather a population of approximately 2.5 million people.

It should be noted that, although they do not have exclusive rooms for the assistance of abused children, the criminal courts in the districts of Icoaraci, Outeiro and Mosqueiro, located, respectively, around 20, 30 and 70 kilometers from Belém, each one of these municipalities has a special testimony room, equipment and skilled professionals. The judicial branches of other municipalities, in addition to receiving processes relating to crimes committed against children and adolescents, also receive other types of processes, because they accumulate several territorial and material jurisdictions. In addition, they do not possess equipment and structure for the implementation of special testimonials. As a rule, the judge in charge of such courts requests for the use of the structure belonging to the Criminal Court for Children and Adolescents of Belém, but the assistance of this type of request is not always possible, due to the great demand in the capital city.

The team that performs the assistance to the victim in Belém is composed by the judge and a prosecutor. The presence of the Public Defender is also very frequent, since the majority of the accused people declare not to be able to afford the cost of a private lawyer. The technical team is formed by a psychologist and a social worker. On the day of testimony, the victim is received by the psychologist about one hour before the scheduled time for the completion of the hearing and is driven to the special room so that his or her testimony is collected. When the testimony begins, the victim is informed of the reason for which he or she is in that place. Then, the psychologist uses designed games and material as a strategy for capturing non-verbal elements in which there may be signs of abuse and, thus, remove a narrative about the fact under investigation. 
If the prosecutor, the judge or the defense wish some specific clarification during the psychologist's interaction with the child, they may request it through the computer installed in the room or an electronic point, both under the direct and exclusive control of the psychologist. She can then enter the answer in the context of dialog in which she and the children are involved.

The type of question used in special testimonies in Belém follows the model and the national and international recommendations mentioned by Mugno, Klemfuss, and Lyon (2016) who consider the open questions the most appropriate strategy to investigate this type of victim. Upon completed the collection of information in special room, the transmission of the testimony to the audience is interrupted, but the psychologist or social worker remains with the child for some time in order to calm her down, if necessary, then is released and delivered to her guardians and can return to her residence. It is difficult to accurately assess to what extent the adoption of such care has effective influence on the judge's decision. Despite the recognition of the validity of the special strategies to take the children's testimony and of the importance of this testimony to the constitution of the evidences, most of the times these procedures are not even mentioned in the records, unlike what occurs in other countries, such as, for example, in the USA, where the correct (or incorrect) application of technical provisions can have a decisive role in the testimonial and consequently on the outcome of the trial. In the processes analyzed in the Court of Belém, the child's testimony taken in the "special" form has not resulted in the predominance of convictions

In cases in which there is the testimony of witnesses in the process, it is observed that they were heard basically to protest about the habits of the child and her propensity to lie or invent stories, which leads us to infer that, if the witness tells that the child has this behavior, the credibility of her testimony tends to collapse. Thus, the child will only have her report considered if its character is not put in doubt by the testimony of a witness or by the opinion of an expert. This situation is particularly delicate in cases in which the expert examination was negative or was not conclusive to confirm the victim's narrative. Taking as an example the cases of complaint of libidinous act, the only evidence becomes the victim's testimony, which can become very weak compared to the testimony of the witness or legal report; in these situations, the possibility of condemnation of the accused is reduced, as indicated in Table 1.

Table 1. Cases sentenced in 2017 in the Criminal Court for Children and Adolescents of Belém, according to the gender of judges

\begin{tabular}{|l|l|l|}
\hline SENTENCE RESULT & Female Judges & Male Judges \\
\hline The Accused Condemnation & 11 & 2 \\
\hline Acquittal & 43 & 12 \\
\hline Extinction of the punishability by death of the defendant or prescription & 8 & 1 \\
\hline Rejection of the complaint of the Public Ministry & 1 & 1 \\
\hline Total & 53 & 26 \\
\hline
\end{tabular}

Source: Libra system the Court of Justice of the state of Pará.

Among the 79 cases analyzed it was found out that that 17 acquittals occurred due to the difficulty finding the victim, who eventually changed address without communicating to the Court or did not attend the hearing although duly notified. The procedures do not contain records that allow us to say with absolute certainty the reason for such withdrawal, which could be attributed to constraints and threats suffered by the child or by her relatives, the fact of the victim and her family members do not believe that the process will result in effective punishment of the guilty or even to the fact of supposing that their physical safety or economic condition of survival could be compromised (Bérgamo \& Bazon, 2012; Chaves \& Costa, 2012).

The second largest contingent of acquittals, amounting 11, is attributed to the lack of coherence between the testimony of the victim and the legal expert report. The reason of the contradictions can be multiple, since failures in the valuation report by manipulation of the child's testimony: this can occur when the child is induced to deny the abuse suffered or to assert an abuse which she did not suffer. This last possibility happens in cases when other factors are involved, such as, for example, parental alienation (Guazzeli, 2007). In this case, the expert can prevail over the child's narrative, which relegates her testimony to a second plan.

The third cause of acquittal has to do with the fact that the victim was less than 14 years old at the time of the facts and affirm that had sexual intercourse with the accused who was more than 18 years old by her own free will and consent and in the context of a loving relationship, despite the ban imposed by her family. 
There are eight of these cases. Although Article 217-A of the Penal Code defines sexual relations with a person of age less than 14 years as rape by suspected violence, because in theory the person in this age range does not have enough discernment to consent to the relationship, among the analyzed processes, there was at least one case in which the judge decided by the acquittal of the defendant, thus contradicting what the law says.

In a broader framework of impunity relating to this type of crime, the time between the occurrence of the fact and the conduct of the proceedings also need to be highlighted. Among the 79 examined cases, the majority (sixtyfive), lasted for a time equal to or greater than two years until the sentence was pronounced. This time is smaller only in cases in which the defendant is arrested provisionally. However, if the accused is under parole, the time for completion of the process is disproportionately long. The oldest event that was analyzed began in 1996 and ended only in 2017, which corresponds to 19 years in progress from the beginning until the final judgment. Beyond this, other fourteen processes were found that were terminated after an average of 15 years in progress. Contrary to what the papers conducted in other countries indicate, the processes that were analyzed, the sex of the judge did not have an important role in the conviction or acquittal of the defendant. As shown in Table 1, the majority of cases in which the judge was female resulted in acquittal, extinction of the punishability or rejection of the complaint, making a total of fifty-five sentences of these types pronounced by the judges, while 14 were pronounced by judges based on the same grounds. In the same way, the age of the victim does not seem to have influenced the number of convictions, because the male and female judges seem to have been restricted to the analysis of the evidence contained in the records, regardless of the age of the victim.

\section{Conclusions}

It is difficult to establish definitively the reason by which a problem as the abuse of children is still present so remarkably in the Brazilian society. Somehow, it is also incomprehensible that the knowledge about the need to protect the victim and blame harshly those who commit this type of offense has not become an absolute priority for all the public institutions related to this issue. As the abuse is usually practiced by any person who is part of the intimacy of the child, a series of factors contributes directly or indirectly to her testimonial falls into disrepute. Objections on the child's memory and her ability to store and report the facts occurred, her propensity or not to create fantasies and even the status given to a specialist in the process often put at stake her credibility. The special testimony rooms that arose as an attempt to obtain more reliable narratives, because were taken under conditions apparently less embarrassing for the child, also reveal their problems. Firstly, there are not universalized, i.e., they are not present in all cities, nor in all courts and criminal courts where they the processes of child abuse are received. Secondly, even when such rooms exist, the way the testimony is taken is technically incipient, if one takes into consideration that, even in therapies carried out in offices, the time for the child to gain confidence and begin to become accessible to the intervention of the therapist is relatively long; it is difficult to imagine that this effect can be achieved properly on the first contact of the child with the psychologist or social worker, as normally occurs in the depositions made to justice, because the time is insufficient to build a relationship of trust which is essential.

Although the city of Belém counts on special testimonial rooms, the universalization of this space is a very distant reality, even for the cities located in the metropolitan region and more distant still to other cities in the state, whose territorial extension is longer than that of some countries. In addition, when the testimony is taken in this type of equipment, its weight in the process still raises many questions. Indeed, in the majority of the analyzed cases, the content of the records was decisive in the process, and this means that the technical evidence and the opinion of an expert overlap to the child's testimony. Probably this is the cause of the predominance of acquittals, even among the judges of the female sex, contrary to what occurs in other countries, where there is a tendency for the condemnation in this situation. The credibility of the child's testimony is a dimension that still needs to be better exploited by new studies that consider other angles of this multifaceted problem.

\section{References}

Ahern, E. C.,Stolzenberg, S. N., \& Lyon, T. D. (2015) Do prosecutors use interview instructions or build rapport with child witnesses? Behavioral Sciences and the Law. doi: 10.1002/bsl.2183

Alexandre, G. C.,Nadanovsky, P.,Moraes, C. L.,\&Reichenheim, M.(2010). The presence of a stepfather and child physical abuse, as reported by a sample of Brazilian mothers in Rio de Janeiro. Child Abuse \& Neglect, 34(12), 959-966. doi: 10.1016/j.chiabu.2010.06.005 
Alexandre, G. C.,Nadanovsky, P., Wilson, M., Daly, M.,Moraes, C. L.,\&Reichenheim, M. (2011). Cues of paternal uncertainty and father to child physical abuse as reported by mothers in Rio de Janeiro, Brazil. Child Abuse \& Neglect, 35(8), 567-573. doi: 10.1016/j.chiabu.2011.04.001

Bérgamo, L. P. D., \&Bazon, M. R. (2012). Abuso físico infantil: avaliando fatores de risco psicológicos em cuidadores notificados. Psicologia: Reflexão e Crítica, 25(2), 256-264.

Bidarra, Z. S., Lessard, G., \& Dumont, A. (2016). Co-occurrence of intimate partner violence and child sexual abuse: prevalence, risk factors and related issues. Child Abuse \& Neglect, 55,10-21. doi: 10.1016/j.chiabu.2016.03.007

Bidrose, S., \& Goodman, G. S. (2000). Testimony and evidence: a scientific case study of memory for child sexual abuse. Applied Cognitive Psychology, 14(3), 197-213. https://doi.org/10.1002/(SICI)10990720(200005/06)14:3<197::AID-ACP647>3.0.CO;2-6

Buck, J. A., London, K., \& Wright, D. B. (2010). Expert testimony regarding child witnesses: does it sensitize Jurors to forensic interview quality? Law and Human Behavior, 35(2), 152164.http://dx.doi.org/10.1007/s10979-010-9228-2

IBGE. Instituto Brasileiro de Geografia e Estatística. (2010). Censo Demográfico 2010. Recuperado de www.ibge.gov.br/home/estatistica/populacao/censo2010/

Cézar, J. A. D. (2007). Depoimento sem dano: uma alternativa para inquirir crianças e adolescentes em processos judiciais. Porto Alegre. Livraria do Advogado.

Chaves, E., \& Costa, L. C. (2012). Technical Study About The Removal Of The Aggressor In Sexual Abuse: offender, family and victim. Psicologia: Teoria e Prática, 14(2), 102-115.

Cooper, A., Quas, J. A., \&Clevelandm K. C. (2014). The Emotional Child Witness: Effects On Juror DecisionMaking. Behavioral Sciences and the Law, 32(6), 813-828.http://dx.doi.org/10.1002/bsl.2153

Da Costa, I. M. M., \& Da Silva, M. J. (2016). "Era Eu Dizendo Uma Coisa e Todo Mundo Dizendo Outra": a constituição de vítima de abuso sexual infanto-juvenil na justiça criminal. Mediações, 21(1), 82. doi: 10.5433/2176-6665.2016v21n1p82

Da Silva Franzin, L. C., Olandovski, M., Vettorazzi, M. L. T., Werneck, R. I., Moyses, S. J., Kusma, S. Z., \&Moyses, S. T. (2014). Child and adolescent abuse and neglect in the city of Curitiba, Brazil. ChildAbuse\&Neglect, 38(10), 1706-1714. doi: 10.1186/s12889-016-3562-3

Dobke, V. M. (2001). Abuso sexual: a inquirição das crianças, uma abordagem interdisciplinar. Porto Alegre: Ricardo Lenz Editor.

Dobke, V. M., Santos, S. S. dos, \&Dell'aglio, D. D. (2010). Abuso sexual intrafamiliar: da notificação ao depoimento no contexto processual-penal. Temas em Psicologia, 18(1), 167-176.

Evans, A. D., Stolzenberg, S. N., Lee, K., \& Lyon, T. D. (2014). Young children's difficulty with indirect speech acts: implications for questioning child witnesses. Behavioral sciences and the law. Recuperado de https://asu.pure.elsevier.com/en/publications/young-childrens-difficulty-with-indirect-speech-actsimplications

Feltis, B. B., Powell, M. B., Snow, P. C., \& Hughes-Scholes, C. H. (2010). An examination of the association between interviewer question type and story-grammar detail in child witness interviews about abuse. Child Abuse \& Neglect, 34(6), 407-413. doi: 10.1016/j.chiabu.2009.09.019

Froner, J. P., \&Ramires, V. R. R. (2008). Escuta de crianças vítimas de abuso sexual no âmbito jurídico: uma revisão crítica da literatura. Paidéia, 18(40), 267-278.

Golding, J. M., Lynch, K. R., Wasarhaley, N. E., \& Keller, P. S. (2015). Courtroom Perceptions of Child Sexual Assault: the impact of an eyewitness. Criminal Justice and Behavior, 42(7), 763781.http://dx.doi.org/10.1177/0093854814568552

Golding, J. M., Wasarhaley, N. E., Lynch, K. R., Lippert, A., \&Magyarics, C. L. (2015). Improving the credibility of child sexual assault victims in court: the impact of a sexual assault nurse examiner. Behavioral sciences and the law, 33(4), 493-507. doi: 10.1002/bsl.2188

Goodman-Delahunty, J., Cossins, A., \&O’brien, K. (2010). Enhancing the Credibility of Complainants in Child Sexual Assault Trials: the effect of expert evidence and judicial directions. Behavioral Sciences and the Law, 28(6), 769-783.doi: 10.1002/bsl.936

Granjeiro, I. A. C. L., \& Costa, L. F. (2008). O estudo psicossocial forense como subsídio para a decisão judicial na situação de abuso sexual. Psicologia: Teoria e Pesquisa, 24(2), 161-169.

https://dx.doi.org/10.1590/S0102-37722008000200005 
Guazzelli, M. (2007). A falsa denúncia de abuso sexual. In M. B. Dias (Ed.), Incesto e alienação parental: Realidades que a Justiça insiste em não ver (pp. 112-139). São Paulo: Revista dos Tribunais.

Guilherme, E., Duarte, S., Farias, R., \&Steidel, M. (2016). Causes of institutionalization of children and adolescents in a shelter in Brazil. European Psychiatry, 33, S568. doi: https://doi.org/10.1016/j.eurpsy.2016.01.1668

Habigzang, L. F., Koller, S. H., Stroeher, F. H., Hatzenberger, R., Cunha, R. C. D., \& Ramos, M. D. S. (2008). Entrevista clínica com crianças e adolescentes vítimas de abuso sexual. Estudos de Psicologia, 13(3), 285292.

Habigzang, L. F., Ramos, M. Da S., \&Koller, S. H. (2005). Abuso sexual infantil e dinâmica familiar: aspectos observados em processos jurídicos. Psicologia: Teoria E Pesquisa, 21(3), 341-348.

Habigzang, L. F., Ramos, M. Da S., \&Koller, S. H. (2011). A revelação de abuso sexual: As medidas adotadas pela rede de apoio. Psicologia: Teoria e Pesquisa, 27(4), 467-473.

Hobbs, S. D., \& Goodman G. S. (2014). Child witnesses in the legal system: improving child interviews and understanding juror decisions. Behavioral Sciences and the Law, 32(6), 681-685. http://dx.doi.org/10.1002/bsl.2151

Johnson, J. L., \& Shelley, A. E. (2014). Effects of child interview tactics on prospective jurors' decisions. Behavioral Sciences and the Law, 32(6), 846-866. https://doi.org/10.1002/bsl.2152

Mcauliff, B. D., Lapin, J., \& Michel, S. (2015). Support Person Presence and Child Victim Testimony: believe it or not. Behavioral Sciences and the Law,33(4), 508-527. http://dx.doi.org/10.1002/bsl.2190

Mugno, A. P., Klemfuss, J. Z., \& Lyon, T. D. (2016). Attorney Questions Predict Jury-eligible Adult Assessments of Attorneys, Child Witnesses, and Defendant Guilt. Behavioral Sciences and the Law,34(1), 178-199. http://dx.doi.org/10.1002/bsl.2214

Pelisoli, C., Herman, S., \& Dell'Aglio, D. D. (2015). Child sexual abuse research knowledge among child abuse professionals and laypersons. ChildAbuse\&Neglect, 40, 36-47. doi: 10.1016/j.chiabu.2014.08.010

Ribeiro, C. (2009). A Criança na Justiça: Trajectórias e significados do processo judicial de crianças vítimas de abuso sexual intrafamiliar. São Paulo: Almedina.

Schaefer, L. S., Rossetto, S., \& Kristensen, C. H. (2012). Perícia Psicológica No Abuso Sexual De Crianças E Adolescentes. Psicologia: Teoria E Pesquisa, 28(2), 227-234. doi: 10.1590/S0102-37722012000200011

Viola, T. W., Salum, G. A., Kluwe-Schiavon, B., Sanvicente-Vieira, B., Levandowski, M. L., \& Grassi-Oliveira, R. (2016). The influence of geographical and economic factors in estimates of childhood abuse and neglect using the childhood trauma questionnaire: A worldwide meta-regression analysis. Child Abuse \& Neglect, 51, 1-11. doi: 10.1016/j.chiabu.2015.11.019 